\title{
Refining Clean Fuels for the Future*
}

\author{
P. Courty' and J.F. Gruson ${ }^{1}$ \\ 1 Institut français du pétrole, 1 et 4, avenue de Bois-Préau, 92852 Rueil-Malmaison Cedex - France \\ e-mail: philippe.courty @ifp.fr - j-francois.gruson@ifp.fr \\ * Paper presented at the OAPEC-IFP Joint Seminar \\ "The Role of R\&D in Improving the Efficiency and Economics in Downstream Industries", \\ 26-28 September 2000, Institut français du pétrole, Rueil-Malmaison, France.
}

\begin{abstract}
Résumé - La production de carburants propres pour l'avenir — Quelles seront les évolutions importantes des carburants dans le futur? Les gaz de pétrole liquéfiés, le gaz naturel pourraient entrer en compétition avec les carburants conventionnels; l'hydrogène et le méthanol auraient un développement conditionné par une percée des piles à combustible dans le domaine des transports. Toutefois, prenant en compte l'évolution future de la demande en carburants, ceux issus du raffinage du pétrole, en particulier l'essence et le gazole, devraient toujours constituer l'approvisionnement principal.

Bien qu'une forte proportion des procédés technologiques et des catalyseurs requis pour répondre à cette évolution soit dès aujourd'hui disponible ou en développement avancé, la part croissante des distillats moyens pose problème au raffinage. Certes, potentiellement, la raffinerie fondée sur les technologies les plus récentes et minimisant la production de fiouls lourds est techniquement au point. Toutefois, sa profitabilité est pénalisée par les investissements et les coûts opératoires importants résultants.

Les challenges futurs liés au pool essence concernent essentiellement l'impact « soufre » des essences de craquage catalytique, l'évolution des contraintes sur les aromatiques et les oléfines, et un possible bannissement des éthers, tout ceci pénalisant l'octane. S'agissant du pool gazole, les défis du futur concernent essentiellement la désulfuration profonde, mais aussi l'hydrogénation des aromatiques et l'ouverture des cycles naphténiques pour satisfaire aux exigences en cétane et aux autres spécifications.
\end{abstract}

La conversion chimique du gaz via le gaz de synthèse demeure une voie privilégiée pour ouvrir la voie aux carburants «propres» du futur. Les technologies Gas to Liquids (GTL) les plus compétitives pourraient tout à fait satisfaire l'accroissement de la demande du futur, sans toutefois diminuer les pertes en carbone associées sous forme de $\mathrm{CO}_{2}$.

En intégrant cet ensemble, il apparaît que la production de carburants «propres » pour le futur est techniquement possible. Les technologies avancées d'hydroraffinage et d'hydroconversion catalytique le permettent et présentent la flexibilité gazole/essence recherchée. Cependant, la réduction des coûts de production demeure le défi clé : les investissements importants requis sont difficilement acceptables avec les marges de raffinage incertaines et volatiles actuelles et probablement futures.

Un dernier point important concerne les émissions de $\mathrm{CO}_{2}$. La mise en place des nouvelles unités de production d'hydrogène requises pour atteindre les spécifications futures des carburants implique des émissions additionnelles importantes de $\mathrm{CO}_{2}$ et la production de carburants propres par conversion chimique du gaz ne résoudra pas ce problème. En conclusion, tout durcissement des spécifications carburants envisagé devrait pouvoir être examiné à la lumière des pertes fatales en carbone $\left(\mathrm{CO}_{2}\right)$ qu'il impliquerait et de ses coûts associés.

Mots-clés : carburants, raffinage, soufre, hydrotraitement, $\mathrm{CO}_{2}$. 


\begin{abstract}
Refining Clean Fuels for the Future - To which extent transportation fuels will reasonably be changed in the coming years? GPL and natural gas are expected to challenge conventional fuels, hydrogen and methanol are bounded to possible fuel cells development. Among others, security of supply, competitive economics and environmental protection issues will be the key to the changes in the coming years. But taking into account expected transportation development, liquid fuels from oil should prevail as the reference energy.

Though most of technologies and catalysts needed for the future are still existing or under marketing plans, the industry has to cope with the growing share of middle distillates. Indeed future zero heavy fueloil refineries are technically feasible through many existing and recent technologies. However their potential profitability is weighed down deeply by the very high investments and operating costs which are tied up.

Tomorrow's main gasoline challenges deal with sulfur in FCC gasoline, aromatics and olefins contents together with a possible ban of ethers, hampering future octane demand and its technical feasibility. In a similar way diesel oil issues for the future imply a very deep desulfurization with possible aromatics hydrogenation and rings opening in order to comply with cetane and polyaromatics ratings.

Natural gas upgrading via syngas chemistry is still expected to open the way to clean fuels for the future via improved and integrated FT's GTL technologies which could as a matter provide most of future increases in clean fuels demand without decreasing the related fatal carbon losses as $\mathrm{CO}_{2}$.

As an overall view, clean fuels production for the future is technically feasible. Advanced hydrorefining and hydroconversion technologies open the way to clean fuels and allow the best flexibility in the gasoline/middle distillates ratio. However, cost reduction remains a key issue since the huge investments needed are faced with low and volatile refining margins.

In addition, $\mathrm{CO}_{2}$ fatal production is bounded with the extra-hydrogen production needed for clean fuels achievements and natural gas upgrading could bring other very clean fuels without solving $\mathrm{CO}_{2}$ emissions drawbacks. Consequently, every fuel specification improvement will have to be balanced with its bounded fatal carbon losses, as $\mathrm{CO}_{2}$, and its extra cost.

Keywords: transportation fuels, refining, sulphur, hydrorefining, $\mathrm{CO}_{2}$
\end{abstract}

\section{INTRODUCTION}

Over the past decade, the world oil sector experienced a dramatic phase of restructuring. Yet, the forthcoming mutations are no less crucial in economic and technological terms. Structural changes in market and environmental pressure will clearly be key issues for the worldwide refining industry.

This evolution will be particularly focused on transportation fuels as it already can be observed in the United States with the Clean Air Act Amendment (CAAA) implementation and in the European Union (EU) with the publication of the new directive relating to the quality of petrol and diesel fuel, but also on the residue "greening" or disposal. This trend will be widely shared more or less all over the world. To which extent transportation fuels will be changed in the coming years should be a key point for the refining industry.

In that sense this presentation will focus successively on the four following topics:

- which future fuels;

- liquid fuels;

- refining issues;

- natural gas upgrading.

\section{WHICH FUTURE FUELS}

It is always important to examine the horizons for possible threats to future oil planning. The challenge for the refining industry could come from the development of new sources for transportation fuels even if the accuracy of this scenario is likely beyond 2010 (Fig. 1). In this sector, the two drivers that could change the game are:

- the need for increased security and diversification of supplies; this is a traditional feature;

- the search for technologies and fuels which offer better environmental protection, both from the urban point of view and from global warming issue.

If we try to draw a calendar for the future, three periods could be identified:

- in the short term, any change made will not be very significant. Oxygenates like methyltertiobutylether (MTBE) or ethyltertiobutylether (ETBE) as blend fuels with a production to grow up to $25 \mathrm{Mt} /$ year could represent at best less than $1 \%$ of the total oil consumption, even if these products are banned (in California) by environmental legislation.

Some microniches for alternative fuels, i.e. natural gas (NGV) and propane-butane mix (LPG) will likely start 


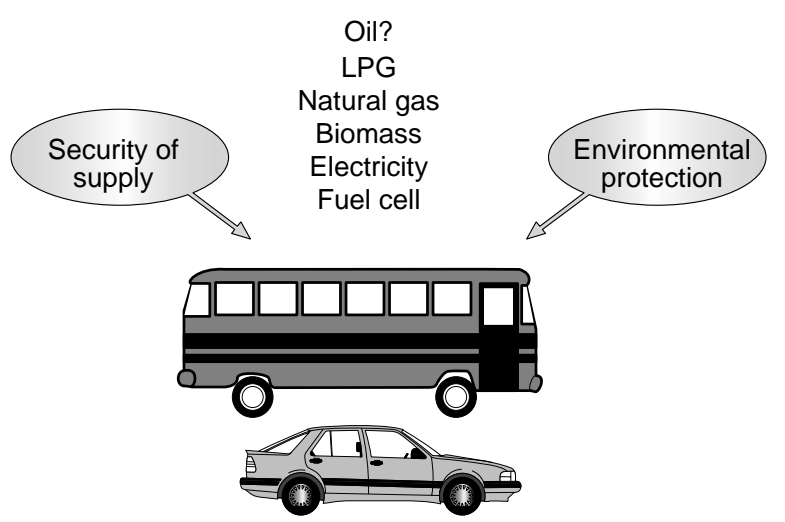

Synthetic fuels from natural gas: Fischer-Tropsch diesel fuel and DME (an equivalent LPG for diesel engine)

Figure 1

Possible new fuels for the future.

appearing in private or public fleet. Although its development is still limited, LPG is a leading one as car manufacturers are now providing attractive vehicles fitted. It should nevertheless be pointed out that the drawback of this product is the lack of massive amount of supply with regards to the transportation fuels demand and so the difficulty to have a significant distribution infrastructure except in some particular areas (e.g. the Netherlands).

NGV is also a useful substitute for automotive diesel fuel and is of interest in particular to heavy-duty vehicles and buses. The only real disadvantage of this solution rests in the high-pressure storage request very penalizing with regards to the weight and indirectly to the driving range of the vehicle;

- in the mid-term: it is highly possible that two options for ultra low emissions or critical zero emissions could start appearing economically. First the hybrid path which combines the advantage of an electrical transmission in terms of local pollution and the flexibility and the agreement (range, etc.) of an internal combustion engine. It could be a better way for deblocking the development of pure electric vehicles.

The second could be the chemical conversion of natural gas to synthetic fuels either via the Fischer-Tropsch process for the production of very high-quality middle distillates, or via new oxygenates like dimethylether (DME), an equivalent for diesel engine to the LPG, or other ethers;

- further along in the time there are of course more uncertainties, but all the previous technologies should be improved and find an increasing position. In addition, hydrogen road is clearly recognized as a potential new transportation energy source even if it is difficult to determine which technology will be the winning one: fuel cells could be a tough competitor as cost, dimensions and durability are seriously improved.

Anyway, it is clear that the environment protection actions are taking more and more importance among the world. It is no longer only an industrial country topic as many newly industrialized countries are, in particular in their new urban areas, very concerned by pollution of atmosphere.

As far as concern, the fuel specification severization is now a classical way for authorities to deal with air quality targets worldwide in relation or not with vehicle posttreatment equipment.

Emissions of major pollutants (carbon monoxide, unburned hydrocarbons, ozone precursors, nitrogen oxides and particulate) will be reduced, significantly over the next several years. This objective supposes to reduce dramatically emissions from motor vehicles, light and duty ones, particularly in urban areas, as called for by the CAAA adopted in the United States and the present directives in Europe. Legislation will continue to evolve, leading to further changes in formulations of motor fuels and also to the promotion of new transportation fuels.

Beyond these "local" pollutions, the global warming issue is now a key feature for the refining and more generally the oil industry, the no-regret strategy gains ground and managers like J. Browne of BP (Browne, 2000). A company like Shell includes it in its policy of development (Royal Dutch Company Website).

In the transportation sector, that means that car manufacturers will have to improve engine efficiency by developing technologies like lean-burn and direct injection engines with no increase of the other pollutants. To achieve these targets, this industry clearly claims for high-quality fuels. But as that will be showed further, this evolution conducts to a dramatic increase of the refinery energy consumption.

Environment is likely to be a durable driver of the refinery mutations, but economics are essential to enable all these changes to come. But taking into account expected transportation developments liquid fuels from oil should prevail as the reference energy.

\section{LIQUID FUELS}

Almost 50\% of the world oil consumption are used for transportation fuels (Fig. 2). This trend will intensify as the demand increases at a rate of $2.9 \%$ per year, thus boosting the oil demand from the 1998 level of 1.6 billion toe to 2.4 billion toe by the year 2010. In the Organization for Economic Cooperation and Development (OECD) countries where individual and public transportation systems are widely available, the growth directly attributable to this sector will be a moderate $1.7 \%$ per year. 
On the other hand, in view of the very low density of vehicles per capita in non-OECD countries and so far the huge potential for expansion, a transportation energy boom of $4.5 \%$ per year is foreseen in that part of the world. In South East Asia, where the urbanization is rising rapidly and where the need for individual and merchandise transportation is expanding due to economic growth, it will expand at an annual rate of $6 \%$.

This shift in the end-uses of oil towards principally light products (gasoline and naphtha) and middle distillates (jet and gasoil) at the expense of heavy fuel oil will remain the second challenge to meet for the oil refining industry (Fig. 3).

\section{PRODUCT QUALITY ISSUES}

More stringent specifications will be clearly the consequences of such evolutions and will principally concern gasoline and diesel fuels firstly, the other products in a less extent.

Globally lead additives will be quickly outlawed from gasoline leading to $100 \%$ unleaded world gasoline market around 2005. In parallel sulfur will have to be taken away of all transportation fuels downward to an extremely low level: it is likely that $50 \%$ of diesel fuel in 2000 will be a 500 ppm quality.

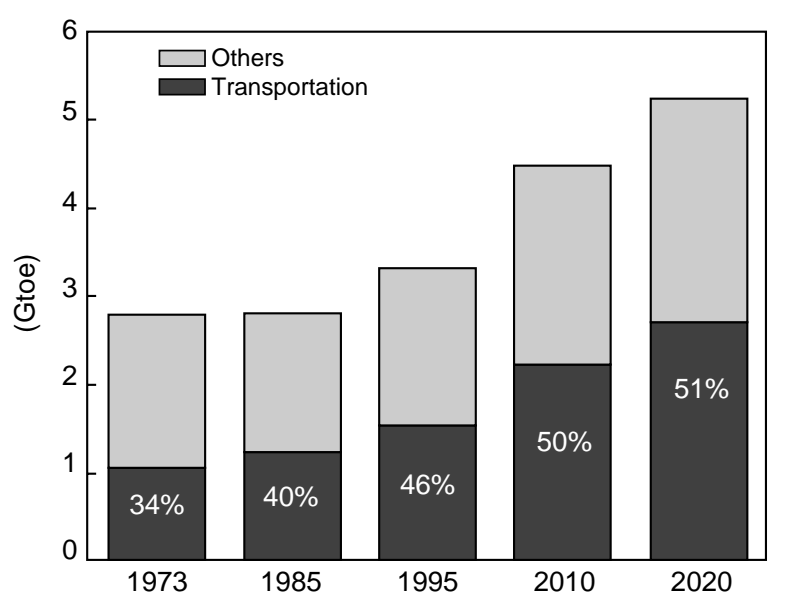

Figure 2

Liquid fuels: share of transportation in the world oil market. Liquid fuels demand leads refining and drives world oil market.

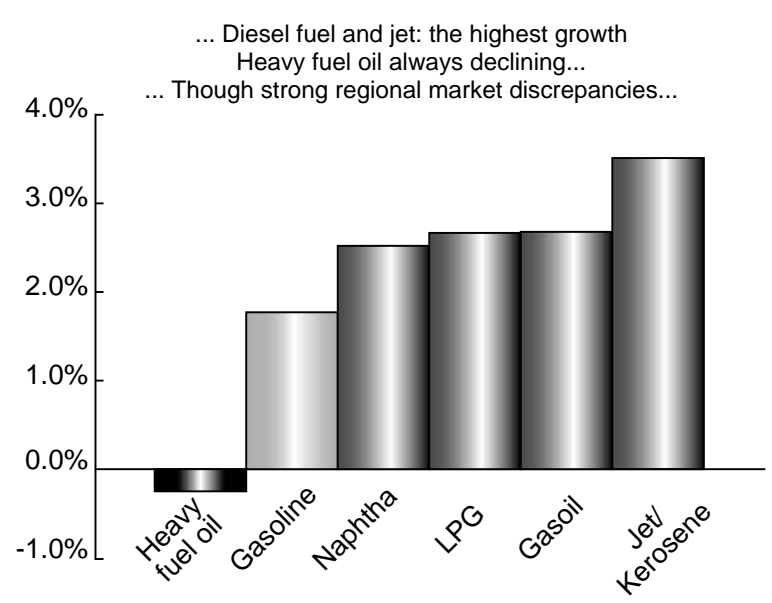

Figure 3

Liquid fuels: 1995-2010, oil product demand increase.

TABLE 1

Liquid fuels: European product quality trends

\begin{tabular}{|c|c|c|c|c|}
\hline Gasoline & 1996 & 2000 & 2005 & 2005-2010? \\
\hline $\begin{array}{l}\text { Sulfur } \\
\text { Benzene } \\
\text { Aromatics } \\
\text { Olefins }\end{array}$ & $\begin{array}{c}500 \mathrm{ppm} \\
5 \% \\
\text { not specified } \\
\text { not specified }\end{array}$ & $\begin{array}{c}150 \mathrm{ppm} \\
1 \% \\
42 \% \\
18 \%\end{array}$ & $\begin{array}{c}50 \mathrm{ppm} \\
1 \% \\
35 \% \\
\text { from } 18 \% \text { to } 8 \% *\end{array}$ & $\begin{array}{c}10-30 \mathrm{ppm} \\
\quad<1 \% \\
<30 \% \\
<10 \%\end{array}$ \\
\hline Diesel fuel & 1996 & 2000 & 2005 & 2005-2010? \\
\hline $\begin{array}{l}\text { Sulfur } \\
\text { Cetane } \\
\text { Polyaromatics } \\
\text { Specific gravity } \\
\text { T95 max }\end{array}$ & $\begin{array}{c}500 \mathrm{ppm} \\
49 \\
\text { not specified } \\
860 \\
370^{\circ} \mathrm{C}\end{array}$ & $\begin{array}{c}350 \mathrm{ppm} \\
51 \\
11 \% \\
845 \\
370^{\circ} \mathrm{C}\end{array}$ & $\begin{array}{l}50 \mathrm{ppm} \\
\text { from } 51 \text { to } 58^{*} \\
\text { from } 11 \% \text { to } 2 \% * \\
\text { from } 845 \text { to } 820^{*} \\
340 \text { to } 360^{\circ} \mathrm{C}\end{array}$ & $\begin{array}{c}10-30 \mathrm{ppm} \\
53 \text { up to } 55 \\
1 \%-2 \% \\
<840 \\
<340^{\circ} \mathrm{C}\end{array}$ \\
\hline
\end{tabular}

* 2005, range of study of AOP II (Bechtel consultants). 
In Europe, the Auto-Oil Programme II (AOP II) launched in 1997 has been achieved in the midst of 2000 and should lead to new specification proposals for 2005 and beyond (Table 1). Today the major features are focused on the sulfur content of gasoline and diesel fuel below the $50 \mathrm{ppm}$ previous expected values. There are many pressures coming notably from the automotive industry to go down to $10 \mathrm{ppm}$ to allow the utilization of new nitrogen oxides $\left(\mathrm{NO}_{\mathrm{X}}\right)$ or particulate after-treatment technologies. The United States are going on the same way for the year 2006.

Other characteristic evolutions like polyaromatic content or final distillation point for diesel fuel are not decided but could be dramatically reduced.

The combustion of heating oil and heavy fuel oils (HFO) are with other fossil fuels responsible both for most of the sulfur dioxides $\left(\mathrm{SO}_{2}\right)$ and for a large portion of the $\mathrm{NO}_{\mathrm{X}}$ emissions from petroleum origins. It is with regard to these two pollutants that limitations have and will continue to be tightened.

Consequences are clear regarding the sulfur content of these fuels, particularly for HFO with specifications of $1 \%$ or $0.5 \%$. An alternative is the flue gas desulfurization, but it is a costly option with solid waste production. The more often this is a strong incitement to shift to natural gas (e.g. power generation).

In addition, like all industrial plants, refineries are sources of pollution. Similarly they discharge hydrocarbons into the air by evaporation and chiefly via combustion plants or catalytic processing: carbon monoxide $(\mathrm{CO})$, carbon dioxide $\left(\mathrm{CO}_{2}\right), \mathrm{NO}_{\mathrm{X}}$, hydrogen sulfide $\left(\mathrm{H}_{2} \mathrm{~S}\right), \mathrm{SO}_{2}$, dust, fines, etc. They are also sources of noise, odor, waste and water discharges.

\section{REFINING ISSUES}

In addition to quality constraints, market demand evolution with its increasing diesel fuel and parallel decreasing heavy fuel oil share is therefore deeply challenging the refining industry though most of technologies and catalysts needed for the future are still existing or under marketing plans (Fig. 4).

Another main issue could deal with the future refinery feedstock. One of the principal characteristics of the oil market over the last decade has been the growth of the production share of the non-OPEC and non-Community of Independent States (CIS) countries. This shift in supply has been accompanied by a higher availability of lighter crudes. In the long term, this trend is questionable. A more recent concern appears with the availability of large amounts of natural gas condensates, which likely require dedicated refineries.

The drawbacks of world crude reserves are their relatively higher densities, sourer and lower product qualities, i.e. heavier crudes with higher sulfur and nitrogen contents. This will be a first important issue for the refining industry.

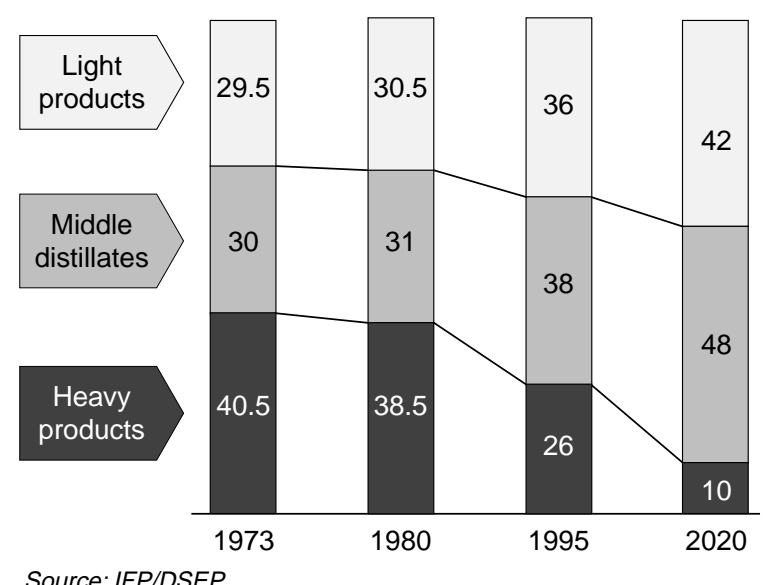

Figure 4

Refining issues: world oil demand evolution.

If the lightening of the supply has given it a good help to meet product quality requirements, this has also generated gasoline regional surpluses. In the future, the refiner will have to implement a technology able to partly receive extra heavy crudes. The projects under development in Venezuela around the Orinoco belt are a good illustration of such an evolution.

Indeed, future zero heavy fuel-oil refineries are technically feasible through many existing and recent technologies. The proposed scheme could meet these 2010-2020's challenges (Fig. 5).

However their potential profitability is weighed down deeply by the very high investments and operating costs, which are tied up. Also, the conversion of residues into clean middle distillates will have to cope with the huge increase of hydrogen needs and of related $\mathrm{CO}_{2}$ emissions.

All the upgrading processes, required either to improve product environmental quality or convert residues, are the most often based on hydrogen utilization. Thus, a key passage point will be the supply of large quantities of hydrogen. The current scenario shows that additional demand for hydrogen will outstrip largely the traditional resources, even if extra could be recovered by better management: other sources will become inevitable (Fig. 6).

Some options available are to generate hydrogen by steam reforming of gaseous effluents or to carry out partial oxidation of a fraction of the residue, permitting the recovery of hydrogen and electricity with fatal and huge $\mathrm{CO}_{2}$ production from 10 to $14.5 \mathrm{t}$ for $1 \mathrm{t}$ of hydrogen, depending upon the roads.

The use of this technology in a way of cogeneration and combined cycles is of great interest by the flexibility offered to the refiner: however these processes are very capitalintensive and their viability strongly depends on electricity sales price. 


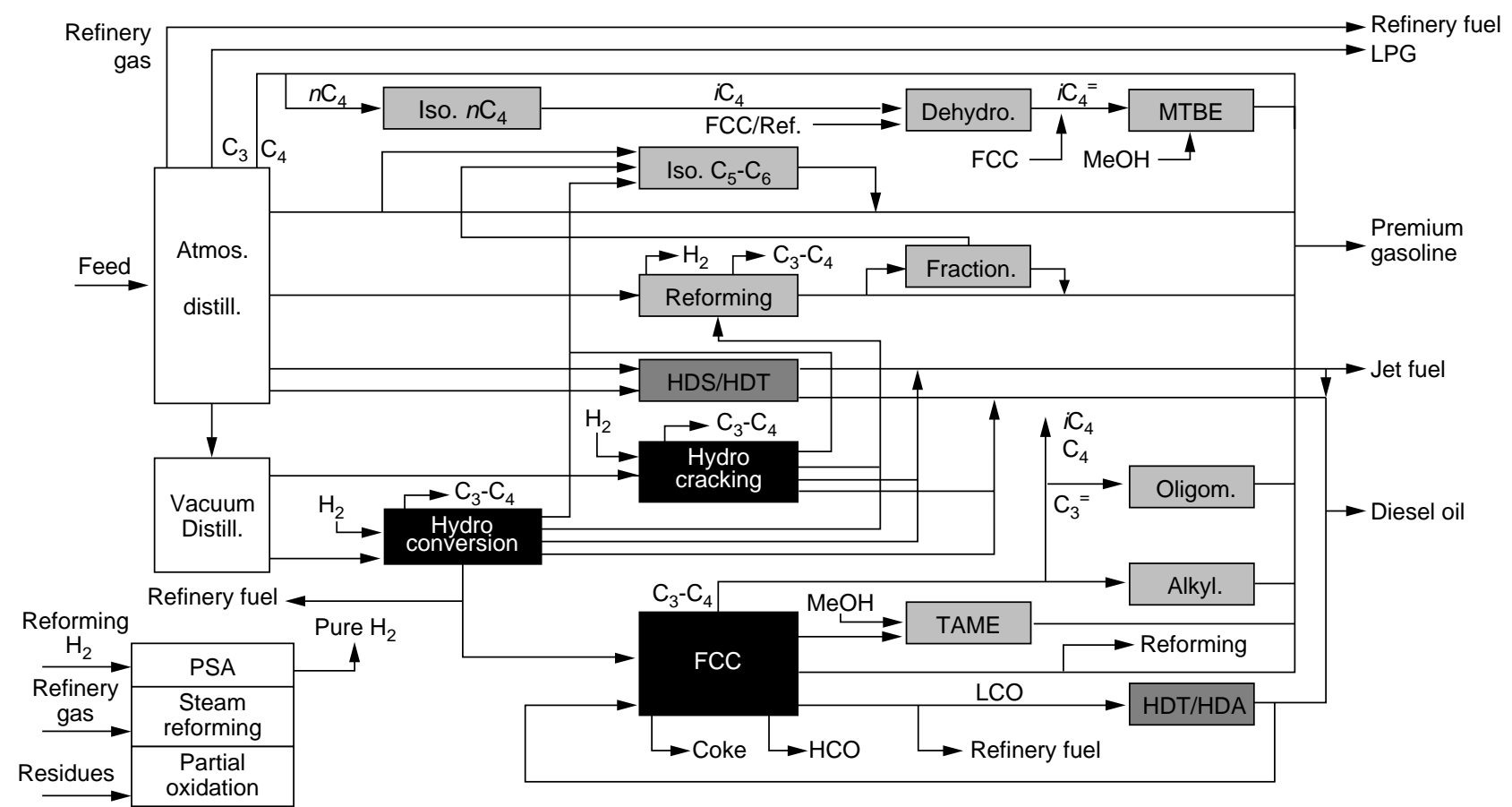

Figure 5

Refining issues: 2010+, non-fuel oil refinery.

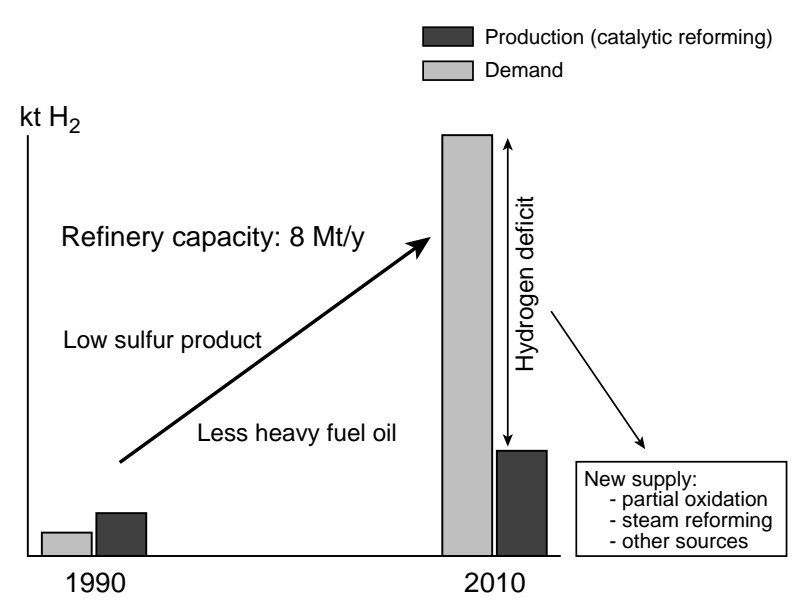

Figure 6

Refining issues: refinery hydrogen balance.

In this context of a general fuel reformulation, hydrotreating technologies will undoubtedly play a leading role. They could answer to various objectives: remove sulfur and nitrogen elements from oil products used as heating and motor fuels, improve the quality of middle distillates, light (kerosene and diesel oil) and heavy as feeds to conversion units. They should also be key options to allow the partial conversion of residues and the upgrading of extra heavy crudes.

If only classical pollutants are considered ignoring the greenhouse gases, these technologies could produce "superclean" or zero emissions fuels. Taking into consideration $\mathrm{CO}_{2}$ emissions, two major problems will have to be solved: the severe operating conditions with poor energy recovery and the high hydrogen consumption (Fig. 1).

All reactions involved in hydroprocessing have the same features: they are exothermic, hence thermodynamically limited above temperatures ranging from $300^{\circ}$ to $500^{\circ} \mathrm{C}$ depending on the reaction and producing heat difficult to recover. They use catalysts having rather low activity and limited selectivity (for instance in terms of the hydrodesulfurization/hydrogenation ratio) which imply the use of high pressures and excess hydrogen resulting in high amounts of released $\mathrm{CO}_{2}$ (Section 5).

Hydrotreating processes cannot be longer considered as zero emissions ones. Minimization of this related $\mathrm{CO}_{2}$ production would have to be tackled in at least two ways:

- optimization of the hydroprocessing scheme including hydrogen stream;

- development of new, more active and/or more selective catalysts. 


\subsection{Gasoline Issues}

This target is completely joined with the reduction of pollutants in motor vehicles. Technical solutions required to attain gasoline quality constraints are available, at least for present crude supply and for pictured standard levels. But the economics are not so clear and the optimum in terms of cost/efficiency has to be discussed.

The three characteristics which are particularly concerned by new limitations are:

- the sulfur: the problem is really focused on the catcracked gasoline (around 30\% to $40 \%$ of the pool) with two main solutions: desulfurization of the fluid catalytic cracking (FCC) feedstock or of the heavy cat-cracked gasoline excluding FCC gasoline end-point reduction.

In one hand, the FCC feed hydrotreating provides many extra benefits: decreasing the sulfur not only in gasoline but also in light cycle oil (LCO) and heavy cycle oil $(\mathrm{HCO})$ and in the regeneration process $\left(\mathrm{SO}_{\mathrm{X}}\right.$ level), reducing the coke production and increasing the conversion ratio. But it fails to directly yield deeply desulfurized gasoline (10 to $20 \mathrm{ppm}$ ).

The second becomes in that sense a compulsory issue and gives substantially milder operating conditions. It consumes less hydrogen but could lead to a significant octane loss in the case of a $95 \%$ sulfur removal. Minimizing this loss requires the combination of selective hydrotreatments depending on the different FCC gasoline streams, and a new catalytic system to avoid hydrogenation of olefins;

- the aromatics (Fig. 7): they are key components of the gasoline pool for octane performance and are mainly produced in catalytic reforming which is today essential for refinery hydrogen supply. A large reduction of their amount would lead to big difficulties, as there is no actual way to change aromatics to high-octane components from naphtha.

Benzene removal does not appear as a technical problem. Three broad options are available for dealing with, depending on economical and regional situations:

- remove precursors from the catalytic reformer feed;

- lower severity and pressure of the reformer;

- post-fractionate and process benzene forward saturation or isomerization;

- the olefin reduction, of which the main source is the front end of the cut of FCC naphtha stream, could be achieved in an attractive way for $\mathrm{C}_{5}$ olefins by their etherification to teramylmethylether (TAME) or by their alkylation.

At the end, the oxygenates (MTBE, ETBE, etc.) offer to the refiners a range of flexibility to optimize their process integration. But MTBE ban tendency in the United States or in few European countries could threat this solution as US consumption represents $60 \%$ of the world demand. New processes like isobutene dimerization and hydrogenation to isooctane could bring alternative.

Anyway, catalytic cracking comes out as the critical unit in the future, as it is the most widespread conversion tool in the world.

\subsection{Diesel Oil Options}

For diesel fuel the industry has to cope with two features (Fig. 8), the growing demand outstripping that of gasoline in some areas and the new severe quality requirements targeted such as sulfur, aromatics (especially the polynuclear aromatics: $11 \%$ for EU in $2000, \%$ ? in 2005) and cetane number.

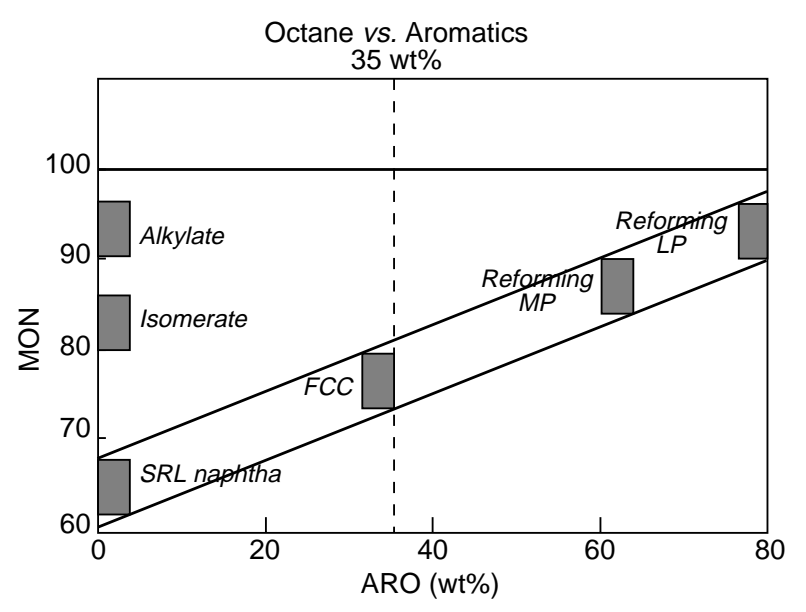

Figure 7

Refining issues: gasoline pool.

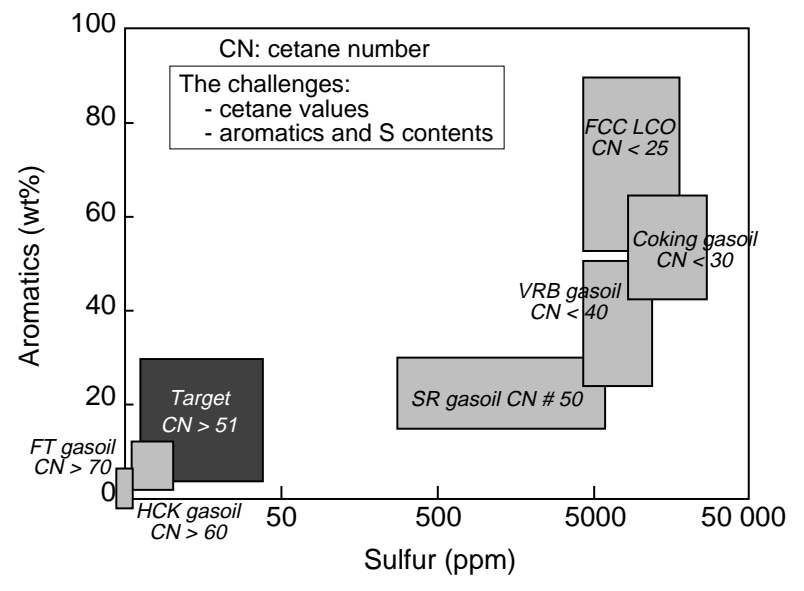

Figure 8

Refining issues: diesel pool components. 
In order to keep pace with these trends, the key unit will be improved hydroprocessing reactor technology in its various options including catalysts, operating conditions and process schemes relating to the wide range of feeds from straight run gasoil (SRGO) to cracked distillates like light cycle oil (LCO). This step-by-step approach will provide refiners with the best solutions for optimizing their current and future needs.

To achieve these goals, the availability of catalysts (used alone or in combination) with selectivity level able to deal with difficult feedstock or/and to meet from simple desulfurization to deep aromatic reduction targets will be essential to optimize operations under milder conditions.

As long as sulfur is only concerned, deep hydrodesulfurization technologies to get even $10 \mathrm{ppm}$ limits are commercial. Higher hydrogen partial pressures will be required for middle distillates obtained from thermal conversion processes or FCC (for instance $8 \mathrm{MPa}$ for a mix $80 \%$ SRGO/20\% LCO).

But new constraints on polyaromatics (around 2\%) will create enhanced duties for the hydroprocessing. Then the best option to adopt will be two-stage hydrotreating schemes with optimized operating conditions, as any cetane improvement involves a severe hydrogenation of aromatics. It will require the use of very active noble metal base catalysts in a second step after a first step of ultra low desulfurization to be conducted under rather mild conditions. Accordingly, hydrogen consumption will be significantly increased by a factor of up to 10 .

If the refiner wants to go further in cetane gain, two routes are possible, of high interest when they are applied to lowcetane and rich-in-aromatics middle distillates from FCC or thermal processes: deep hydrogenation with restricted conversion on special catalysts or hydrocracking of such feeds, mixed with the normal straight run feed. These would help to bring all these above products to very severe specifications.

In both cases, huge investments and higher operating costs will occur and $\mathrm{CO}_{2}$ emissions will increase dramatically. Anyway, the choice of the final technology route will depend largely on the initial refinery configuration, so the optimization for the refiner will require process schemes as flexible as possible. If very high cetane is required or if significant pool components are released from diesel fuel, new solutions could involve very high-quality products to be added to the pool: synthetic diesel oil from Fischer-Tropsch (FT) reaction or heavy oxygenated compounds. All these options will involve natural gas as feedstock.

\section{NATURAL GAS UPGRADING}

In the recent years, natural gas reserves have been continuously increasing and are now equivalent to oil (Fig. 9). It is also expected that natural gas consumption should increase rapidly in the world in particular to achieve the enormous growth for new and low-pollution power generation investments.

The chemical conversion of natural gas is not new and today the most developed options (Fig. 10) are the methanol production ( 25 to $30 \mathrm{Mt} / \mathrm{y}$ with or not MTBE) and ammonia; but both represent limited volumes. Today, from methanol, new products to be used as alternative transportation fuels have been proposed, like DME.

Direct synthesis has been already proven so DME (cetane number $>70$ ) is a possible candidate as a clean fuel for diesel engines: first fleet results show very low $\mathrm{NO}_{\mathrm{X}}$ and particulate matter emissions. But as for any new gaseous fuel, the implementation of distribution facilities has to be faced.

Concerning MTBE, there are a lot of discussions about the toxic and carcinogenic associated risks and a ban regulation due to them; this feature has been pointed out by the Californian authorities. In the European Union the under chemical review could conclude that on the human health risks there are no serious concerns but some actions should be decided for the environment risks.

The emergence of gas-to-liquids (GTL) technologies as a possible solution to monetizing stranded gas reserves or to limit gas flaring has been lately discussed for a viable alternative to liquefied natural gas (LNG). In addition GTL potentially offers a supply of very high quality middle distillates when demand for diesel fuel and jet kerosene is forecast to grow strongly with increasingly stringent quality specifications (Fig. 11).

This integrated process including syngas production, Fischer-Tropsch synthesis and final hydroisomerization and separation steps has to face with two major challenges to

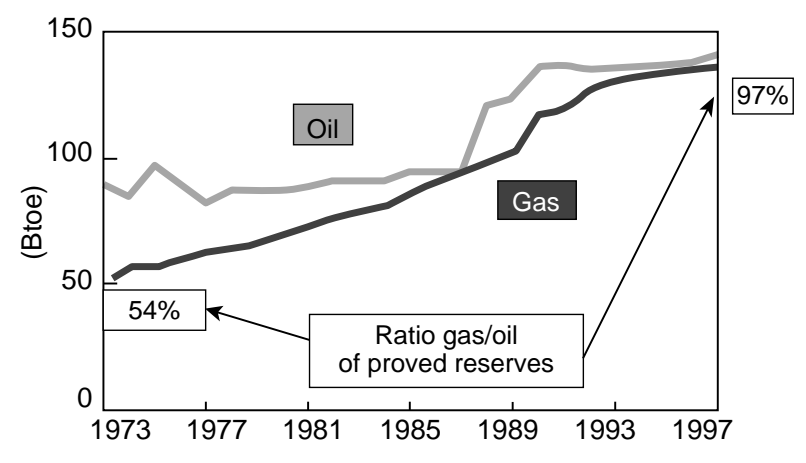

- NG resources are equivalent to oil resources

- Cheap NG, fatal NG (zero cost) are available $\rightarrow$ NG upgrading opens

- Technologies (GTL, DME, etc.) are under development

the way to clean fuels for the future

\section{Figure 9}

Natural gas upgrading: the world proven oil and gas reserves evolution. 


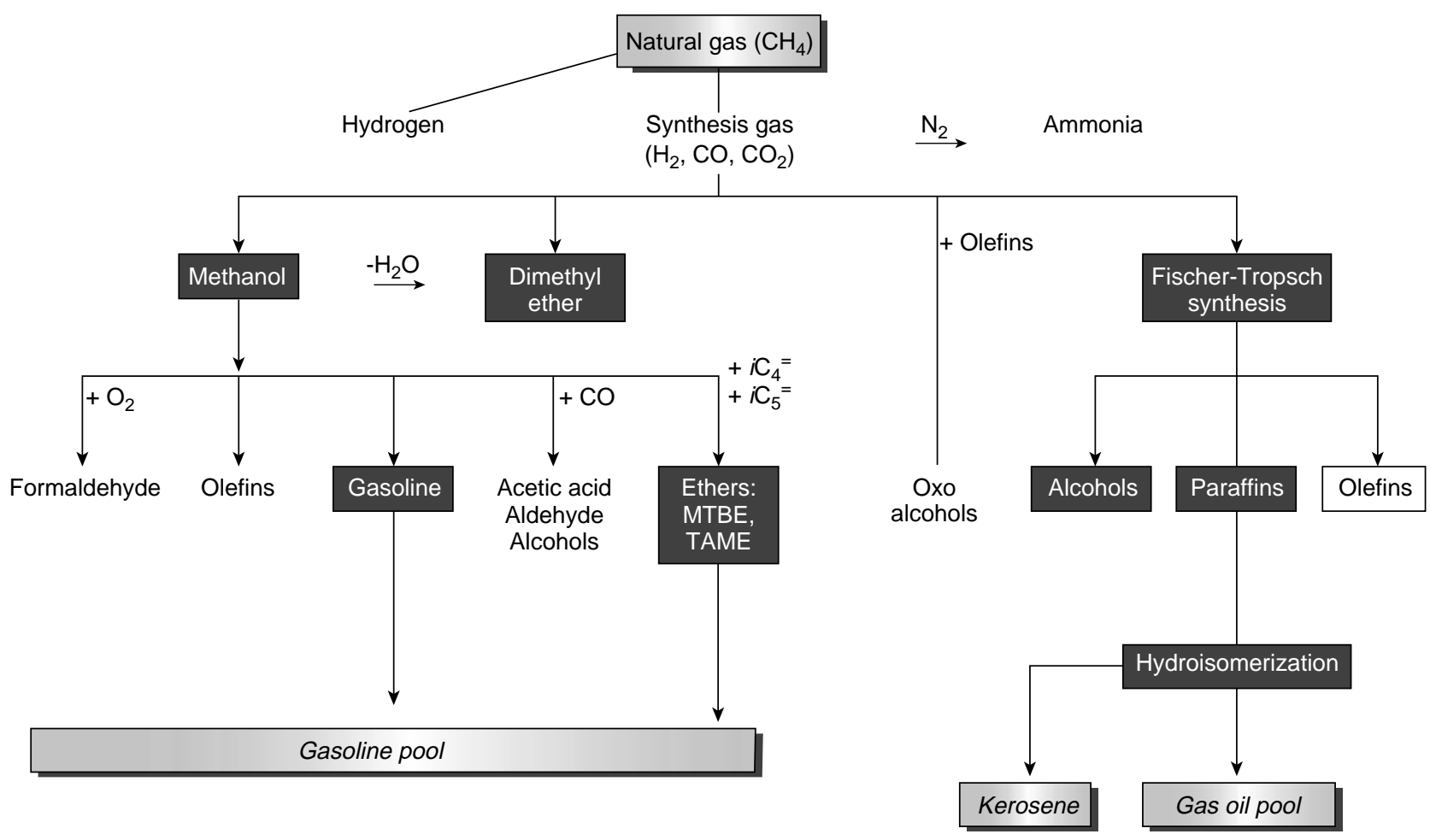

Figure 10

Natural gas upgrading: chemical conversion of natural gas.

FT Synthesis: integrated gas-to-liquids process

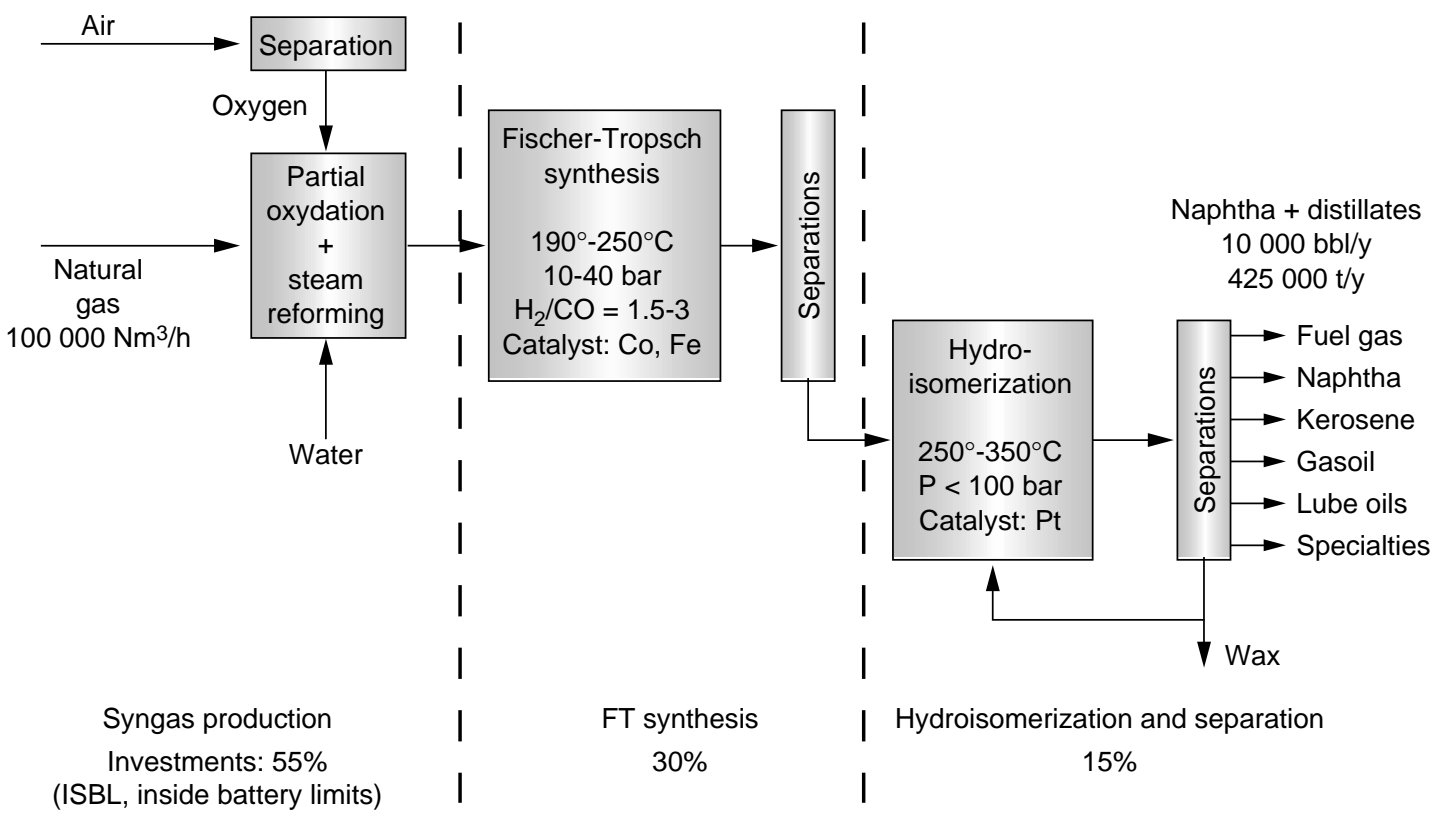

Figure 11

Natural gas upgrading: integrated gas-to-liquids process. 
become a future (2010-2020) significant provider in clean diesel fuels:

- to lower capital expenditures below \$25 000/bpsd via membrane technologies for oxygen separation, improves syngas and FT processes;

- to achieve $\mathrm{CO}_{2}$ emissions from well to wheel not exceeding those of hydrocracking units.

\section{CONCLUSION}

The worldwide refining industry is more and more under continuous environmental pressure and market requirements for light products to meet the growth of the transportation sector. If only classical pollutants are considered, advanced hydroprocessing technologies could achieve any level of purification that may be required, while being nearly zero emissions and allow best flexibility in terms of gasoline/middle distillate ratio. But a dramatic focus must be done on optimization of the different schemes in order to decrease investment and operating cost.

However the $\mathrm{CO}_{2}$ emissions in the refinery, associated with hydrogen production, will have to be taken into account when new fuel specifications are considered, some of them bringing minor air quality improvements, while imposing important extra $\mathrm{CO}_{2}$. Natural gas upgrading could provide clean and performing diesel fuels (DME, FT) without solving $\mathrm{CO}_{2}$ emissions drawbacks.

In the environmental regulation evolution, well-to-wheel analysis should be developed to ensure a coherent and costefficient approach while avoiding investment wastes.

\section{REFERENCES}

Browne, J., Sir (2000) 16th World Petroleum Congress, Calgary, June 11-15.

Royal Dutch Company WebSite and various publications.

Final manuscript received in July 2001 